\title{
ARTICLE
}

\section{Hayek's Spiritual Science}

\author{
Jerry O'Shea* \\ POLIS, University of Cambridge \\ ${ }^{*}$ Corresponding author. E-mail: jpc82@cam.ac.uk
}

(Received 15 September 2019; revised 20 December 2019; accepted 15 October 2020)

This article argues that Hayek's thought had a consistent epistemological core that he developed with the aim of undermining prevailing positivism and replacing it with a metaphysical and spiritualistic philosophy of science. This becomes clear when an intellectual-historical method is used to elucidate Hayek's psychological and methodological works. We see that the approaches and arguments he found most convincing were those of nineteenth-century neo-Kantianisms, Gestalt psychology, vitalism, phenomenology, and theological mathematician Georg Cantor. Hayek thought his spiritual science superior because it explained "the place where the human individual stands in the order of things," thereby clarifying science's epistemic standpoint, but also its meaning. The article will be of interest to scholars of neoliberalism and contemporary politics because its reading of Hayek suggests that the allegiance between, and apparent attractiveness of, Hayekian and religious conservative thought may have something to do with their common claims to marry order, freedom, and purpose.

He was also somebody looking for an answer to the problem of religion and he had a continuous internal battle with the concept we call God. He always resisted an anthropomorphic God. He didn't want a God just a little bit more than man.

Priest and academic Johannes Schasching, officiating the Catholic funeral of Friedrich Hayek, Neustift am Walde, Austria, 4 April $1992^{1}$

Friedrich Hayek is renowned for his epistemological contributions to political economy, namely that unconscious knowledge is dispersed throughout society. Such knowledge, for Hayek, is only utilized when the free market establishes a "spontaneous order" within the bounds of constitutional rules based upon a principle of protecting property and negative liberty. Consequently, Hayek's epistemology has been explored in a voluminous literature, the vast majority of which deems him to be some form of positivist. ${ }^{2}$ A recent turn, however, has questioned Hayek's

\footnotetext{
${ }^{1}$ Alan Ebenstein, Hayek: A Biography (Basingstoke, 2001), 317-18.

${ }^{2}$ Prominent examples include Bruce Caldwell, "Hayek the Falsificationist? A Refutation," Research in the History of Economic Thought and Methodology 10/1 (1992), 1-15; Caldwell, "Hayek's Scientific Subjectivism," Economics and Philosophy 10/2 (1994), 305-13; Paul Lewis, "Hayek, Social Theory, and terms of the Creative Commons Attribution licence (http://creativecommons.org/licenses/by/4.0/), which permits unrestricted re-use, distribution, and reproduction in any medium, provided the original work is properly cited.
} 
scientific status by drawing attention to moral and theological aspects of his work. ${ }^{3}$ The problem is that neither of these two positions is able to account for the other without ignoring significant aspects of Hayek's thought, contriving "phases," or adopting an implausible deus ex machina such that his continuous and extensive forays into a range of scientific fields were supposedly entirely driven by a desire to disguise ideology as science. ${ }^{4}$

I propose that both positions misunderstand Hayek's philosophy of science because of their common failure to take seriously both the scientific and spiritual aspects of Hayek's work. Employing an intellectual-historical approach, we see that Hayek thought his science was "true" science precisely because of its moral, metaphysical, and spiritualistic aspects. ${ }^{5}$ Hayek's epistemology did not pretend to be "scientific" by feigning neutrality or objectivity; rather it upheld the validity of value judgments, intuition, metaphysical beliefs, and even ideology. Though valid in scientific inquiry, these were by no means equally "true"; some produced a more accurate description of the world. Examples discussed in this article-methodological individualism, psychological theories that (from introspection) affirmed individuals as distinct wholes, and Wittgenstein's mature work-show that Hayek was most convinced by work that was consciously value-laden and that refused to discredit what we cannot observe.

Since his first academic essay in 1920, Hayek aligned his view with schools of thought that were considerably more metaphysical than the Viennese empiricist tradition that many scholars seek to place him in, namely nineteenth-century post-Kantian philosophical psychology, the Berlin school of Gestalt psychology, vitalism, and Husserlian phenomenology. ${ }^{6}$ Throughout his academic life, Hayek

the Contrastive Explanation of Socio-economic Order," Critical Review 25/4 (2013), 386-408; Jan Willem Lindemans, "Hayek's Post-positivist Empiricism: Experience beyond Sensation," Advances in Austrian Economics 15 (2011), 143-70; Scott Scheall, "Hayek the Apriorist?", Journal of the History of Economic Thought 37/1 (2015), 87-110; Scheall, "Lesser Degrees of Explanation: Further Implications of F. A. Hayek's Methodology of Sciences of Complex Phenomena," Erasmus Journal for Philosophy and Economics 8/1 (2015), 42-60. Further examples are discussed in Section I.

${ }^{3}$ Wendy Brown, In the Ruins of Neoliberalism: The Rise of Antidemocratic Politics in the West (New York, 2019); Angus Burgin, The Great Persuasion: Reinventing Free Markets since the Depression (Cambridge, MA, 2012), 103; Sean Irving, Hayek's Market Republicanism (London, 2020); Quinn Slobodian, Globalists (Cambridge, MA, 2018); Jessica Whyte, "The Invisible Hand of Friedrich Hayek: Submission and Spontaneous Order," Political Theory 47/2 (2019), 156-84; Jessica Whyte, The Morals of the Market (London, 2019).

${ }^{4}$ It is the scientific camp that mostly ignore moral and theological aspects, or they explain them purely as "moral functionalism," as in Viktor Vanberg, "Spontaneous Market Order and Social Rules: A Critical Examination of F. A. Hayek's Theory of Cultural Evolution," Economics and Philosophy 2/1 (1986), 75100, and Jack Birner, "Moral Functionalism," in Jack Birner, P. Garrouste, and T. Aimar, eds., F. A. Hayek as a Political Economist (London, 2002), 26-50. For phases see Philip Mirowski, "Naturalizing the Market on the Road to Revisionism," Journal of Institutional Economics 3/3 (2007), 351-72, at 3656. For ideology see Naomi Beck, Hayek and the Evolution of Capitalism (Chicago, 2018), 155.

${ }^{5}$ I use Hayek's distinction of "true" individualism or rationalism, which corresponds to the science he considers "true," as opposed to idealist or constructive rationalism. See F.A. Hayek, "Individualism: True and False" (1945), in Hayek, Individualism and Economic Order (Chicago, 1948), 1-32, at 3 n. 1. Also see Hayek, "History and Politics," in Hayek, ed., Capitalism and the Historians (Chicago, 1954), 3-30, at 5.

${ }^{6}$ For a discussion of the relationships between these schools of thought see Gisueppe Bianco, "Philosophies of Life," in P. E. Gordon and W. Breckman, eds., The Cambridge History of Modern European Thought, vol. 2 (Cambridge, 2019), 153-75. 
thought humans had to be studied in light of their unique purposiveness, "vital processes," and "entire being." This, I propose, was a metaphysical view that closely coincided with the praxeology of his mentor and friend, Ludwig von Mises (1881-1973). Mises maintained an a priori belief in human purposiveness, arguing that "action is the essence of his nature and existence, his means of preserving his life."7 Returning to psychology after his polemical works against economic planning in the 1940s, Hayek was aware that professing his metaphysical views might put him "at the risk of being condemned with Professor Mises as holding views conflicting with the whole trend of modern scientific development." 8 Despite this fear, and his ambition to bring the "whole trend of modern scientific development" with him, he never hid his metaphysical views. To the contrary, he tried to use the language of modern scientific development to demonstrate that his metaphysical views were conducive to science as a pursuit of truth.

This project culminated in what I consider a landmark work-“Rules, Perception and Intelligibility" (1962) —in which Hayek divided "nature" into the physical part that is less complex than our minds, and the "supernatural" part that is more complex than our minds and therefore autonomous, inexplicable, and almost entirely inaccessible. He situated humans and their science in the middle. Science, for Hayek, only made sense to the extent that its practitioners posit the existence of a higher entity that (1) lays down the basic rules according to which our minds and the world operate, and (2) provides humans with a unique complexity, purposiveness, and epistemic position from which they can explain the physical world and-to a very limited extent-each other. Hayek thought his metaphysical science offered a more accurate description of the world, but crucially of a world in which order, freedom, and purpose necessarily exist. More specifically, Hayek's science affirmed an ordained order to the universe and human actions, freedom for the individual within that order, and purpose or meaning in the dual sense that each individual has a place in the order and that there is meaning behind each and every individual action.

With regard to humanity's epistemic position, Hayek thought that if a scientist wants to claim that their investigations in some way correspond to reality, then they posit the existence of something closely akin to "God" whether they think so or not. Why, then, do I not call his science theological? Hayek held strong religious beliefs as a child, but lost faith in a Christian God when, at the age of fourteen, he asked several priests what God is and found their responses unsatisfactory. ${ }^{9}$ In later life, Hayek identified as "agnostic." 10 He never ruled out the existence of an entity with some of the characteristics that we attribute to God, but he did not believe in any doctrinal concepts of such an entity, or at least not in any of those he was aware of. ${ }^{11} \mathrm{He}$ predominantly used the terms "supra-conscious order" and "supraconscious system" to refer to a supersystem that was considerably larger than "spontaneous order" or "cultural evolution" because it governed the regularities

\footnotetext{
${ }^{7}$ Ludwig von Mises, Human Action (San Francisco, 1996; first published 1949), 18.

${ }^{8}$ Friedrich Hayek, "Review of Mises's Nationalöknomie" (1941), reprinted in Hayek, Collected Works, vol. 4, ed. P. G. Klein (Chicago, 1992), 149-52, at 152.

9"Hayek Interviewed by Earlene Craver," Side Two, 1978, UCLA Oral History Archive, transcript, 20.

${ }^{10}$ Stephen Kresge and Leif Wenar, Hayek on Hayek: An Autobiographical Dialogue (London, 1994), 62.

11 "Hayek Interviewed by Robert Chitester," Side Two, 1978, UCLA Oral History Archive, transcript, 489.
} 
in nonorganic and organic matter, as well as providing the grounds for consciousness itself. $^{12}$

To demonstrate the above, I focus on Hayek's writings on humanity's intention and capacity to explain the world. Consequently, it is necessary to put Hayek's endorsements of specific institutions, religions, or economic arrangements to one side in this article. We can only hope to properly understand those views, their origins, and their potential appeal when we first concentrate on the spiritual aspects of Hayek's science itself.

The article is divided into five sections that run broadly chronologically. Section I shows how the existing literature struggles to reconcile the scientific and spiritual Hayek. In opposition to the conventional account of the young Hayek, section II demonstrates that he consciously rejected Viennese empiricism and aligned his thought with thinkers who were closer to the spiritualistic lineage of Naturphilosophie than to the positivism(s) of their day. ${ }^{13}$ Section III explains how, after returning to methodological topics after the war, Hayek developed his younger self's psychological theory in order to justify the existence of an all-encompassing and omnipresent supersystem that provides rules, purposiveness, and meaning. In section IV, I substantiate the argument that Hayek thought his science demonstrated that the existence of intentional action (also explicitly referred to as free will) must necessarily be considered an a priori truth, thereby providing a more robust foundation for Mises's praxeology. Section V shows how my exposition of Hayek's spiritual science can be brought to bear on his politics and economics, specifically with regard to his lesser-known view that, in order to prevail, liberalism and science had to reunite with one another but also with the Catholic Church. I thereby suggest the importance of this for those who wish to understand "neoliberal" thought, as well as its alliance with religious conservative thought.

\section{I}

Those who discuss Hayek as a scientific thinker tend to concentrate on his epistemology and methodology. The fierce debate on these issues is unsurprising considering that Hayek drew on manifold sources to produce an epistemology and methodology that was as unorthodox as it was complex. The debate is crucial because Hayek's lasting contribution to economics was, both on his own and on popular accounts, his explication of "dispersed knowledge" and the cognate theory of "spontaneous order."

The central dispute is whether Hayek was a scientific or nonscientific thinker. Within the first camp-those who broadly hold that Hayek was scientific-typical views are those of Bruce Caldwell and Viktor Vanberg. Caldwell holds that Hayek affirmed "a modernistic scientific worldview," while Vanberg considers Hayek's

\footnotetext{
${ }^{12}$ Friedrich Hayek, "Rules, Perception and Intelligibility" (1962), in Hayek, Studies in Philosophy, Politics and Economics (London, 1967), 43-65, at 59-61, Hayek, "Notes on the Evolution of Systems and Rules of Conduct," in Hayek, Studies in Philosophy, Politics and Economics, 66-81, at 66.

${ }^{13}$ For a brief history of the influence of Naturphilosophie in germanophone life sciences see Bianco, "Philosophies of Life," 156-7.

14"Hayek Interviewed by Armen Alchian," Side Two, 11 Nov. 1978, UCLA Oral History Archive, transcript, 425. For spontaneous order see Friedrich Hayek, Law, Legislation and Liberty, vol. 1 (Chicago, 1973), Ch. 2.
} 
methodology to be "naturalistic subjectivism" and thus "entirely compatible with an empiricist methodology."15 A fracas emerged within the scientific camp following Terence Hutchinson's argument that there were two Hayeks: the Misesian "Hayek I" who believed in a priori knowledge, and, after "Economics and Knowledge" (1937), the Popperian Hayek who believed that knowledge should be subject to falsification. ${ }^{16}$ Views on the matter now range from Hayek being neither Misesian nor Popperian, to being part-Misesian and part-Popperian throughout his works. ${ }^{17}$

It seems to go largely unnoticed, however, that Hayek's position was that "the difference between the views which Professor Mises has long held and the modern 'hypothetico-deductive' interpretation of theoretical science (e.g., as stated by Karl Popper in 1935) is comparatively small, while both are separated by a wide gulf from the naïve empiricism which has long been dominant." 18 This article holds that Hayek was always Misesian on the most fundamental premise of praxeology: that the "axiom of action" must be accepted a priori as the foundation of all social-scientific knowledge.

Scholars in the "scientific" camp often look to Hayek's ideas on psychology. ${ }^{19}$ Manfred Streit, a Mont Pèlerin Society member and founder of the F. A. von Hayek Society, set an unfortunate precedent in 1993 by claiming that Hayek "wanted to replace metaphysics with neurophysiology." ${ }^{20}$ My argument is diametrically opposed to that view. A presentist literature distorts Hayek's view in an attempt to situate him on the frontier of twentieth-century science. ${ }^{21}$ Scholars in Streit's wake see Hayek's psychological works as attempts to shore up empiricism. Mistaken claims such as that the young Hayek was "a rigorous follower of what became the ideas of the Vienna Circle" result from a failure to grasp the nineteenth-

\footnotetext{
${ }^{15}$ Caldwell, "Hayek's Scientific Subjectivism," 309. Viktor Vanberg, “Austrian Economics, Evolutionary Psychology, and Methodological Dualism," in R. Koppl, ed., Evolutionary Psychology and Economic Theory (Kidlington, 2004), 155-99, at 180.

${ }^{16}$ T. W. Hutchison, The Politics and Philosophy of Economics: Marxians, Keynesians and Austrians (Oxford, 1981), 210-19.

${ }^{17}$ For neither Misesian nor Popperian, see Bruce Caldwell, "Hayek the Falsificationist?"; and Bruce Caldwell, "A Skirmish in the Popper Wars: Hutchison versus Caldwell on Hayek, Popper, Mises, and Methodology," Journal of Economic Methodology 16/3 (2009), 315-24. For part both, see Viktor Vanberg, "The 'Knowledge Problem' as the Integrating Theme of F.A. Hayek's Oeuvre," in Hayek, Collected Works, vol. 14 (Chicago, 2018), 1-112, at 34; and Scheall, "Hayek the Apriorist?".

${ }^{18}$ Hayek, "Review of Mises's Nationalöknomie," 148.

${ }^{19}$ Jack Birner, "The Surprising Place of Cognitive Psychology in the Work of F. A. Hayek," History of Economic Ideas 7/1 (2009), 43-84. David Tuerck, "Economics as Mechanism: The Mind as Machine in Hayek's Sensory Order," Constitutional Political Economy 6 (1995), 281-92. Many examples in William Butos, ed., The Social Science of Hayek's “The Sensory Order”, Advances in Austrian Economics 13 (2010), especially Leslie Marsh, "Hayek: Cognitive scientist avant la Lettre," 115-55.

${ }^{20}$ Manfred Streit, "Cognition, Competition, and Catallaxy in Memory of Friedrich August von Hayek," Constitutional Political Economy 4 (1993), 223-62, at 227.

${ }^{21}$ For example, Gary Dempsey, "Hayek's Evolutionary Epistemology, Artificial Intelligence, and the Question of Free Will," Evolution and Cognition 2/2 (1996), 139-50. Carste Hermann-Pillath, "The Brain, Its Sensory Order, and the Evolutionary Concept of Mind: On Hayek's Contribution to Evolutionary Epistemology," Journal for Social and Biological Structures 15/2 (1992), 145-87.
} 
century German philosophical-psychological debates that Hayek was intervening in, as I show in section II. ${ }^{22}$

Often focusing on the psychological and cybernetic aspects of his work, a number of scholars consider Hayek to present a mechanistic philosophy (also described as physicalist or monist), or at the very least a naturalism that permits "emergent" relationships, denoting a situation in which purely physical interactions give rise to an entity with properties that are not reducible to its constituent parts. ${ }^{23}$ However, section III shows that, for Hayek, the "emergent" processes behind the spontaneous orders of mind and economy are distinct and operatively separate from their constituent elements. Mind and economy have lives of their own.

Criticisms of Hayek as mechanistic include conservative thinkers Roger Scruton and Ed Feser. Scruton believed that Hayek places market rationalities above all other spheres and traditions. ${ }^{24}$ Feser, a Catholic apologist, has a deeper understanding of Hayek and argues that he showed great promise as a Catholic metaphysician until he recoiled from affirming the Aristotelian-Scholastic notion of goaldirectedness as built into matter, meaning that "his own escape from scientistic prejudice was arguably less than complete." 25 This article presents evidence that should redeem Hayek in Feser's eyes, perhaps helping to explain the unholy alliance between "neoliberal" and religious conservative thought.

Mechanistic interpretations of Hayek are also offered by his opponents. For instance, placing him in the context of his ideological-political project, Daniel Stedman Jones stated that Hayek's thought was "based in dry economic processes." ${ }^{26}$ Most prominently, Philip Mirowski deems Hayek to have been an orthodox economist in his younger years, then as "relatively Mysterian" from the mid-1930s to "sometime after 1945," but ultimately a peddler of a doctrine of "double truth," filtering mechanistic themes into economics in his mature writings in order to disguise ideology as science. ${ }^{27}$ Reading Hayek as disingenuous in his extensive use of spiritualistic ideas both before and after the "anti-scientism" writings that characterize the so-called "Mysterian" phase is implausible to my mind, and, considering the consistent infusion of the spiritualistic and the metaphysical throughout his work, the division of his thought into phases is also unhelpful. This article argues that phases help us understand certain shifts in content and approach, but that, with the exception of Hayek's "conventional" economic period

\footnotetext{
${ }^{22}$ Jack Birner, "Popper and Hayek on Reason and Tradition," Philosophy of the Social Sciences 44/3 (2014), 263-81, 227.

${ }^{23}$ Tuerck, "Economics as Mechanism." Paul Lewis, "Ontology and the History of Economic Thought: The Case of Anti-reductionism in the Work of Friedrich Hayek," Cambridge Journal of Economics 41/5 (2017), 1343-65.

${ }^{24}$ Roger Scruton, "Hayek and Conservatism," in Edward Feser, ed., The Cambridge Companion to Hayek (Cambridge, 2006), 208-31.

${ }^{25}$ Edward Feser, "Hayek, Popper, and the Causal Theory of the Mind," Advances in Austrian Economics 15 (2011), 73-102, at 97.

${ }^{26}$ Daniel Stedman Jones, Masters of the Universe (Oxford, 2014), 112. Slobodian at times gets close to a mechanistic interpretation; see his Globalists, 165, 227-8.

${ }^{27}$ Mirowski, "Naturalizing the Market," 365-6. For "double truth" see Philip Mirowski, Never Let a Serious Crisis Go to Waste (London, 2014), 68. For cyborg themes see Mirowski, Machine Dreams (Cambridge, 2002), 238-41. For market as "information processor," see Mirowski, Never Let a Serious Crisis Go to Waste, 78.
} 
spanning the early 1920 s to 1936 , his works exhibit remarkable continuity with regard to their epistemological cores.

The difficulties faced by those who see Hayek as scientific have been exacerbated by a small but prominent recent literature that highlights the moral and religious dimensions of Hayek's work, thereby deeming him "unscientific." This interpretation is not entirely new, with an early proponent being James M. Buchananfriend of Hayek and president of the Mont Pelèrin Society from 1984 to $1986 .^{28}$ Hayek realized, according to Buchanan, that "scientific truth, as such, has little going for it." ${ }^{29}$ Buchanan saw spirituality as part of the "soul of classical liberalism." Still, he thought it "useful to separate two persons here, Hayek the social scientist, and Hayek the classical liberal, legal-political-social philosopher." ${ }^{30}$ In such fashion, interpreters are unable or unwilling to consider Hayek's thought a coherent project. $^{31}$

The literature in the "Hayek-is-unscientific" camp is usually presented as a response to Foucault's notion that "economics is a discipline without God." 32 From the "Birth of Biopolitics" lectures, it appears that Foucault believed that Hayek and the ordoliberals, rather than focusing on the limits of human rationality, based their arguments on "the rationality of the atomistic behavior of homo oconomicus." ${ }^{33}$ In 2019, Jessica Whyte argued that Hayek and other neoliberals put cultural values and the "morals of the market" above economic rationality. Her attention is on human rights discourse, however, and although Hayek's defenses of Catholic institutions are mentioned briefly in the context of Chile, they are described as merely "supports for a liberal market." ${ }^{4}$ This underplays the extent to which, from at least 1947, Hayek thought science should ally itself with religion, and specifically the Catholic Church. I return to this in the final section. Nonetheless, the persuasiveness of Whyte's argument concerning neoliberal moralism in general, combined with Melinda Cooper's work on neoliberal social conservativism, recently led Wendy Brown to revise her previous "characterization of neoliberalism's world-making rationality focused exclusively on its drive to economize all features of existence." 35 But Brown still considers Hayek's "theological critique" to be mounted against "sovereignty" as manifested in "God, the king, or the state." 36 This article questions that view.

\footnotetext{
28“Interview with James M. Buchanan," Austrian Economics Newsletter, Fall 1987, 4.

${ }^{29}$ James M. Buchanan, Why I, Too, Am Not a Conservative: The Normative Vision of Classical Liberalism (Northampton, MA, 2005), 64.

${ }^{30}$ Ibid., 86.

${ }^{31}$ Further examples abound. See Chandran Kukathas, Hayek and Modern Liberalism (Oxford, 1989), 206; Norman P. Barry, "The Road to Freedom," in Jack Birner and Rudy van Zijp, eds., Hayek, Co-ordination and Evolution (London, 1994), 141-63, at 160; John Gray, "The Friedrich Hayek I Knew, What He Got Right-and Wrong," New Statesman, 30 July 2015, at www.newstatesman.com/politics/ 2015/07/john-gray-friedrich-hayek-i-knew-and-what-he-got-right-and-wrong.

${ }^{32}$ Michel Foucault, The Birth of Biopolitics: Lectures at the College de France, 1978-79, ed. M. Senellart, trans. G. Burchell (Basingstoke, 2008), 282.

${ }^{33}$ Ibid., 282.

${ }^{34}$ Whyte, The Morals of the Market, Ch. 4, "Modernising Chile."

${ }^{35}$ Brown, In the Ruins of Neoliberalism, 10-11.

${ }^{36}$ Ibid., 70, 202-3 n. 43. Melinda Cooper, Family Values: Between Neoliberalism and the New Social Conservatism (New York, 2017).
} 
Hayek's project was not about removing sovereignty from God, the king, or the state, but rather about making God (as the incomprehensible supersystem) sovereign of the universe, humans, and the products of their actions (such as the market), while reinstating the king or the state as the earthly sovereign authority ordained by God. The earthly sovereign's role is to uphold tradition, which, as we will see, is the means through which the supersystem's rules can be glimpsed, and to enforce the "Constitution of Liberty," which limits the power of its members to interfere with the work of the supersystem. ${ }^{37}$ For reasons of space, this article focuses on the former aspect of the project-making God (the supersystem) sovereign - which, I propose, constitutes the epistemological and ontological foundation of Hayek's project. We must bear in mind that this was closely intertwined with the political-economic aspect of Hayek's work, though this article can only endeavor to briefly illustrate the main areas of overlap and influence in that regard.

The question that is most often asked of Hayek's intertwining of his political-economic and epistemological ideas is to what extent the former occasioned the latter. Naomi Beck explores Hayek's psychological works but concludes that his scientific forays are ultimately a "veneer covering a deeply ideological argument in favor of free market capitalism." ${ }^{38}$ Hayek's science is attacked as "outdated" and inconsistent with the evolutionary tradition he placed himself in. ${ }^{39}$ Beck's work is typical of successful attempts to question the objective scientific standing of some of the core foundations of "neoliberal" thought by illustrating the highly politicized nature of "neoliberal" economics. ${ }^{40}$ However, I contend that critiques that focus on Hayek's moral and theological aspects are more successful when they point to his political activities, reactionary conservativism, problematic political-economic thought, and often repugnant moral views, than when they claim to expose him as unscientific. There are two main reasons for this. The first is that Hayek's main epistemological views underpinning his science were worked out long before his political project. Indeed, Hayek identified himself as a "Fabian socialist" at the time that he wrote his first academic essay-a key psychological and methodological work. ${ }^{41}$ The second is that the "unscientific" critique overlooks just how idiosyncratic Hayek's notion of "science" was. Once this is explicated, accusing Hayek of being "unscientific" has little bite, because we see that he spent a lifetime opposing "science" in the contemporaneous, "modern" sense. Of course, this does not detract from the fact that there are inconsistencies within Hayek's arguments themselves. ${ }^{42}$ My point is that critiquing those arguments for being unscientific upon the then predominant definition of science (at least in the West) does not

\footnotetext{
${ }^{37}$ F. A. Hayek, The Constitution of Liberty (Chicago, 2011; first published 1960).

${ }^{38}$ Beck, Hayek and the Evolution of Capitalism, 155.

${ }^{39}$ Ibid., 8.

${ }^{40}$ Perhaps the best known are Burgin, Great Persuasion; Nancy MacLean, Democracy in Chains (London, 2017); Jamie Peck, Constructions of Neoliberal Reason (Oxford, 2010); Philip Mirowski and Dieter Plehwe, eds., The Road from Mont Pèlerin: The Making of the Neoliberal Thought Collective (Cambridge, MA, 2015).

41"Hayek Interviewed by Craver," 10. Friedrich Hayek, "Contributions to a Theory of How Consciousness Develops," trans. Grete Heinz, in Hayek, Collected Works, 14: 321-47.

${ }^{42}$ Beck, Hayek and the Evolution of Capitalism, for instance, systematically explains logical contradictions in Hayek's evolutionary arguments.
} 
achieve a great deal. To the contrary, the persuasiveness of Hayek's arguments, to many, may lie precisely in the fact that they were unscientific by prevailing standards, as discussed in the conclusion.

\section{II}

Hayek said his studies in psychology as a young man "taught [him] a great deal on the methodology of science," and that "the basic idea" behind his epistemology had been achieved "in 1920." His later "theory of complex phenomena" was a product of his "experience gained in economics applied to [his] original problem." ${ }^{44}$ It is this "basic idea" and "original problem" of his epistemology that concerns us in this section. I offer an alternative history of Hayek's Vienna days, focusing on his noneconomic studies, which are critical in understanding the spiritual and metaphysical features of his science. I show that his epistemological views were strongly opposed to physicalist explanations of consciousness and the empiricism of Ernst Mach (1838-1916) and others who "dominated discussion in Vienna," with whom Hayek is incorrectly aligned. ${ }^{45}$ In fact, whenever Hayek touched upon epistemological issues, he sided with non-positivist neo-Kantians, vitalism, Gestalt psychology, phenomenology, and other schools broadly situated within the Naturphilosophie tradition, opposing the "dogmatic-atomistic" views that he associated with Mach and which strongly informed the logical positivism-especially of proponents of planning in the socialist calculation debates like Otto Neurath-that he so reviled. ${ }^{46}$ For Hayek, epistemology should seek answers to the same questions explored by Kant and those in his shadow, hence his statement: "so as far as psychology is concerned, I am really a ghost from the 19th century."

Having traced cerebral nerve fibers for an anatomist in Zurich in 1919-20, Hayek wrote his first academic essay in 1920, Beiträge zur Theorie der Entwicklung des Bewußtseins (Contributions to the Theory of the Development of Consciousness), which ambitiously tackled the mind-body problem. The young Hayek's interest in natural science is well documented. Caldwell's claim that, for Hayek, the "scientific worldview was a bulwark against much that seemed archaic" epitomizes the typical narrative of his formative years. ${ }^{48}$ Hayek's psychological treatise was in fact directed against Vienna's "scientific worldview." In Beiträge, alongside two later elaborations-the lecture "Das Wesen des Geistigen" (The Nature of Mind or The Essence of the Mind/Spirit) (1949), and The Sensory Order (1952, henceforth TSO)-Hayek argued that "one of the basic problems of psychology" was really a philosophical question: "what is the place of mind

\footnotetext{
43"Hayek Interviewed by Axel Leijonhufvud," 1978, UCLA Oral History Archive, video (the transcript here is inaccurate), 1:04-1:06.

${ }^{44} \mathrm{Ibid}$.

45"Hayek Interviewed by Craver," 16.

${ }^{46}$ Hayek, "Contributions to a Theory of How Consciousness Develops," 321.

${ }^{47}$ Friedrich Hayek, "The Sensory Order after 25 Years," in Hayek, Collected Works, 14: 382-90, at 382.

${ }^{48}$ Kresge and Wenar, Hayek, 36. Bruce Caldwell, Hayek's Challenge (Chicago, 2004), 135. Ebenstein, Hayek, 12-15. Bruce Caldwell, "Hayek and the Austrian Tradition," in Feser, The Cambridge Companion to Hayek, 13-33, at 19.
} 
in the realm of nature?"49 The other, related question driving his psychological work was more narrowly epistemological: "how do we know when our experiences are true perceptions and when they are mere images?" ${ }^{50}$ Even asking the question in that form was a critique of the "all too exclusively empirical approach and of an excessive contempt for 'speculation"' in psychology. ${ }^{51}$

In his two later psychological works, Hayek retained the 1920 essay's focus on the Kant- and Naturphilosophie-influenced natural scientists Johannes Müller (1801-58), Hermann von Helmholtz (1821-94), the emergentist (proto-gestalt) psychologist Wilhelm Wundt (1832-1920), William James, and, less favorably, positivist-empiricist physicist and psychologist Ernst Mach. ${ }^{52}$ Hayek's debt to Mach has led some interpreters to conclude that he exhibits a "physicist's understanding of the nervous system." ${ }^{53}$ Mach's psychological discoveries were important to Hayek's notion of the "system of connections," but agreement with Mach ended there. ${ }^{54}$ Beiträge was a critique of Mach's view that psychology was an empirical science studying what it falsely considered to be isolated "simple or pure sensations" that "serve as the building blocks for all consciousness phenomena." ${ }^{55}$ On the first page of Beiträge, Hayek stated-with Mach in the crosshairs-that the work was "in the sharpest opposition to the prevalent 'dogmatic-atomistic concept of sensations' and to any concept relying on a primal, clear-cut association of consciousness event and brain process." ${ }^{56}$ Mach's physicalism and monism were "unjustified reductionism." 57

Hayek did state that Beiträge offered a "general physiological explanation," but he was clear that it was an explanation that was physiological only because he wanted to build a "speculative" theory from what we know about relatively simple cognitive events. ${ }^{58}$ Equating "psychic and physiological phenomena" must be avoided because "science has gone too far in simplifying and isolating phenomena, in the belief that it could safely disregard the multiplicity of ongoing processes and deduce consciousness processes from simple chains of physiological processes." ${ }^{59} \mathrm{It}$ is difficult to confirm the extent to which Hayek was also attributing blame to logical positivism, as it was still in its early years in 1920, but he was certainly anticipating logical positivism's use of Mach. Moreover, while in Zurich, Hayek had attended a lecture where the Vienna circle's founder, Moritz Schlick, presented his book Allgemeine Erkenntnislehre (1918). ${ }^{60}$ Discussing Mach and Schlick, Hayek

\footnotetext{
${ }^{49}$ Friedrich Hayek, "Das Wesen des Geistigen," Box 104, Folder 20, Hayek Papers, Hoover Institution; Hayek, The Sensory Order (hereafter TSO), reprinted in Hayek, Collected Works, 14: 113-317, at 135.

${ }^{50}$ Friedrich Hayek, "What Is Mind?" (Grete Heinz trans. of "Das Wesen des Geistigen"), in Hayek, Collected Works, 14: 348-60, at 349.

${ }^{51}$ Hayek, TSO, 119.

${ }^{52}$ Ibid., $116-17$.

${ }^{53}$ Barry Smith, "The Connectionist Mind: A Study of Hayekian Psychology," in S. Frowen, ed., Hayek: Economist and Social Philosopher (London, 1997), 9-29, at 15.

${ }^{54}$ Hayek, TSO, 171.

${ }^{55}$ Hayek, "Contributions to a Theory of How Consciousness Develops," 332.

${ }^{56}$ Ibid., 321.

${ }^{57}$ Ibid., 333.

${ }^{58}$ Ibid., 321.

${ }^{59}$ Ibid., 333.

${ }^{60}$ Kresge and Wenar, Hayek on Hayek, 63.
} 
recalled that "it was actually through them that I became aware positivism was just misleading in the social sciences." ${ }^{\text {"I }}$ In TSO, Hayek traced a line leading from Mach to the Vienna circle, whom he mocked for holding a "metaphysical belief in the ultimate 'reality' and constancy of the phenomenal world for which there is little justification." ${ }^{\text {"T2 }}$ This was not an indictment of metaphysics, but a comment on the hypocrisy of the Viennese empiricists, whose crusade against metaphysics had the opposite effect. This also explains the meaning of the final sentence of Beiträge, in which Hayek said that Mach "overturned" Kant's "a priori structures of apperception," but his own work means that "Mach's elements, sensations, may have suffered the same fate." ${ }^{63}$ If one overturns Kant, and then overturns the overturning of Kant, one may well be back with Kant. I believe this was Hayek's intended meaning. In the printed version of "The Primacy of the Abstract" (1969), which discussed the same psychological issues as Beiträge and TSO, Hayek added a footnote to say that he "did not mention in [his] oral exposition ... the obvious relation of all this to Kant's conception of the categories that govern our thinking-which I took rather for granted." critiqued Kant, it was for putting too much faith in human reason, meaning he was "tinged" with "constructivist rationalism." 65

Influenced by Gestalt psychology, neo-Kantians, and Bergson, Hayek held that science had forgotten the truth that "the act of becoming conscious includes more, namely a connection with the apprehending subject's entire being." ${ }^{166}$ Since at least the early nineteenth century, Naturphilosophie's Aristotle- and Kant-inspired view of nature as containing an immanent purposiveness (Zweckmässigkeit) or vis viva (living force) had been contested by those seeking to discredit vital forces as metaphysical speculation and/or to explain them as physical forces. In Beiträge, Hayek made vitalist claims such as that sensory "impressions" only occur "together with impulses stemming from other sources (including the organism's vital processes)." ${ }^{\prime 7}$ Indeed, Hayek emphasized "that Henri Bergson reached very similar conclusions" to his own, also being a "firm opponent of this atomistic conception." ${ }^{\text {6 }}$

These views came from Hayek's student group at Vienna, the Geistkreis (Mind Circle). ${ }^{69}$ He reminisced, "methodological interests" were "brought by some of my colleagues who went elsewhere for a semester-when people like [Alfred] Schutz and [Felix] Kaufmann went to Freiburg to study under Husserl, while [Herbert] Furth and [Max] Mintz went to Heidelberg for a semester, they brought back

\footnotetext{
61"Hayek Interviewed by Craver," 16.

${ }^{62}$ Hayek, TSO, 301.

${ }^{63}$ Hayek, "Contributions to a Theory of How Consciousness Develops," 347.

${ }^{64}$ Friedrich Hayek, "The Primacy of the Abstract" (1969), in Hayek, Collected Works, vol. 15 (Chicago, 2014), 314-37, at 323 n. 28.

${ }^{65}$ Friedrich Hayek, "Kinds of Rationalism" (1965), in Hayek, Collected Works, 15: 39-56, at 52.

${ }^{66}$ Hayek, "Contributions to a Theory of How Consciousness Develops," 323.

${ }^{67}$ Ibid., 334.

${ }^{68}$ Ibid., 333.

${ }^{69}$ This name was given to the group by Martha Steffy Brown (originally Braune), mocking the male chauvinism of their all-male group that refused, unlike the Mises Kreis, to admit a "girl," as Hayek stated in "Hayek Interviewed by Axel Leijonhufvud," transcript, 37.
} 
philosophical ideas." ${ }^{\text {70 }}$ Hayek was referring not only to phenomenology but also to the legacies of southwestern neo-Kantians like Wilhelm Windelband (1848-1915) and Heinrich Rickert (1863-1936). ${ }^{71}$ It was to these neo-Kantian-inspired friends that Hayek "spoke on psychology" and "at that time expounded to them what became [his] Sensory Order book."72 His friend Alfred Schutz (1899-1959) had a strong interest in Bergson's vitalism, and presented his phenomenological sociology to the Geistkreis and Mises Kreis throughout Hayek's years in Vienna. ${ }^{73}$ The importance of the Hayek-Schutz relationship is expanded upon in section IV, but it suffices to note here that Hayek's mind was steeped in the post-Kantian philosophical tradition, and not simply positivist psychology or Austrian-school economics.

In Beiträge, then, we see the psychological and philosophical roots of Hayek's methodological individualism in his secondhand (later firsthand) knowledge of phenomenology, and his readings of Bergson and neo-Kantians. We also see the roots of his belief in a supersystem determining the basic structure of the universe and our cognitive functioning in his in-depth engagement with post-Kantian philosophical psychology. The latter seems to have gone almost entirely unnoticed in the literature, and understanding it requires explaining how and why Hayek intervened in the nativistisch-empiristisch debate, which rumbled through mid-nineteenth-century post-Kantian life sciences into early twentieth-century psychology. ${ }^{74}$

It is understandable that scholars have not dived into the nativistischempiristisch debate, as it involved a dense discussion of physiological optics. The real stakes, however, were how we should understand the origins and role of innate brain structures. Helmholtz's empiristisch position stated that little is "given" to humans except a brain functioning according to general principles by which each human interacts with the world and constructs their vision of it. ${ }^{75}$ Leaving aside considerable debate, this view was similar to Kant's "form" of space. The nativistisch position, first attributed to Ewald Hering (1834-1918), held that everything in our brains ultimately arose from sensations, and that the capacity to locate objects in space was "native" in the sense that it was acquired phylogenetically from the experience of our ancestors. ${ }^{76}$

Hayek sided with Helmholtz - the "greatest of them all"-claiming that his position in the nativistisch-empiristisch debate was "very close to the theory developed here," and that Hering held an "illegitimate interpretation." 77 Hayek concurred

\footnotetext{
70"Hayek Interviewed by Leijonhufvud," transcript, 31.

${ }^{71}$ For Hayek citing Rickert, Windelband and an extensive discussion of their thought, see Friedrich Hayek, The Counter-revolution of Science (London, 1952), 215, 248, 309.

72 "Hayek Interviewed by Leijonhufvud," 36.

${ }^{73}$ Ibid., 36-8. For more on Schutz and Hayek see Mark Smith, Rethinking State Theory (Abingdon, 2000), 116-17.

${ }^{74}$ For the best accounts see Gary Hatfield, The Natural and the Normative: Theories of Spatial Perception from Kant to Helmholtz (Cambridge, MA, 1990), Ch. 5. Also see David Cahan, Hermann von Helmholtz and the Foundations of Nineteenth-Century Science (Berkeley, 1993), 173-203.

${ }^{75}$ Helmholtz first made the distinction in his Handbuch der physiologischen Optik (Leipzig, 1867), 441, 594, 809-18. An English translation is available by J. P. Southall, Treatise on Physiological Optics, vol. 3: The Perceptions of Vision (Menasha, 1925), esp. 607-25.

${ }^{76}$ Hatfield, Natural and Normative, 181-92.

${ }^{77}$ Hayek, TSO, 266; for Hering see ibid., 144.
} 
with Helmholtz's notion of "unconscious inference," but criticized him for eventually supporting the Hering-Mach "conception of a pure core of sensation." Helmholtz was right to emphasize the brain's unconscious processing but failed to commit fully to the view that such automatic processes were "the sole factors" that determine consciousness. ${ }^{79}$ For Hayek, the inexplicability of cognitive processes, and the specific rules by which they operate, meant that there could never be such a thing as a "sensation" that could be isolated and analysed, and therefore that empiricism was a chimera. One reason for scholars failing to see the extent of Hayek's attack on empiricism may be that empiristisch is taken to mean empiricist, though the former refers exclusively to a theory of the psychogenesis of sensory perceptions and the latter is a separate methodological position. Scholars of the debate usually translate empiristisch as "empirist" to distinguish it from methodological empiricism. ${ }^{80}$

In fact, Hayek rejected Mach's empiricism along with the Hering-Mach theory that experiential knowledge is transmitted to subsequent generations. ${ }^{81}$ Hayek denied that "morphological structure is transmitted by the germ cell from generation to generation," but rather held that our mind's "fundamental ever reasserted makeup is a function of the regularities of nature," while each "specific elaboration in individual beings results from the kind of experiences encountered" by them. ${ }^{82}$ Arguing that we construct our own sensations within the regularities of nature, Hayek cited Hans Henning, famous for having introduced a classification of odors. ${ }^{83}$ He thought that Henning's work suggested that his own theoretical psychology might be supported by empirical studies. One might be able to employ "professional tasters and samplers of wine, spirits, tobacco," and see if intensive training of their olfactory abilities might unleash the "human sense of smell," which in "an earlier state of development" was "probably much greater than that which we use." ${ }^{84}$ Hayek apparently took it upon himself to personally conduct such experiments, admitting in 1978 to having "tried thirty-six different snuffs." ${ }^{" 85}$ The structure of our sensory organs, for Hayek, was the blueprint upon which each individual could develop what and how they perceived.

Because of the regularities of nature, of which our mind is part, there is no "unorganized sensory data," no Jamesian "blooming buzzing confusion." 86 Our minds are purposive wholes that result from and operate within natural laws. This was, I hold, the core of Hayek's later theory of a complex supersystem that determines the rules by which our minds operate but that also makes free will possible. This theory would come to inform Hayek's views on political economy because, in both the mind and the economy, freedom came from structure, and not vice versa.

\footnotetext{
${ }^{78}$ Ibid., 266.

${ }^{79}$ Ibid.

${ }^{80}$ Hatfield, Natural and Normative, 273 and Appendix A.

${ }^{81}$ For Mach as a supporter of Hering and as "persistently critical of Helmholtz" see Cahan, Hermann von Helmholtz, 203.

${ }^{82}$ Hayek, "Contributions to a Theory of How Consciousness Develops," 345

${ }^{83}$ Ibid., 249.

${ }^{84}$ Hayek, TSO, 268, 274-6.

${ }^{85}$ "Hayek Interviewed by Chitester," 461-2.

${ }^{86}$ Hayek, "Contributions to a Theory of How Consciousness Develops," 268.
} 


\section{III}

Almost exactly a year after the publication of The Road to Serfdom (1944), Hayek was trying to "elaborate the psychological implications of [his] Scientism articles," referring to the 1942-4 works that began by stating that "we spontaneously perceive" through "pre-conscious learning," and concluded with a discussion of "spontaneous social formations." 87 The "psychological implications" of the articles seem to refer to Hayek's criticism of the "materialist interpretation of history" on the ground that "if we knew how our present knowledge is conditioned or determined, it would no longer be our present knowledge." ${ }^{\prime 8}$ Minds and society are both spontaneous orders that we are incapable of directing to desired ends because we can never be conscious of the processes that determine their functioning.

Nonetheless, Hayek admits that "there may, perhaps, be sense in the statement that to a greatly superior mind our present knowledge would appear as 'relative' or conditioned in a certain manner by assignable circumstances." ${ }^{89}$ In fact, the notion of a superior mind-like entity determining the rules by which mind and society operate is unproblematic until "collectivists" reach the false conclusion that "some special theory" can identify these rules. ${ }^{90}$ Hayek's return to psychology, then, was an attempt to demonstrate that we can never access many of the "regularities of nature" described in Beiträge. Demonstrating this in the case of the functioning of the mind was not simply intended to show, by analogy, that individuals cannot know the laws of society. Rather, it would show that there is something akin to a "greatly superior mind" responsible for determining the regularities underpinning mind and society. This section describes how Hayek developed these arguments in the late 1940s and the 1950s through an application of Gestalt psychology and systems theory to metaphysical questions.

Regarding the complex processes that Hayek's psychological works describe, references to Gestalt ("organization" or "whole") psychology have attracted the most scholarly attention because of its supposed influence on Hayek's concept of "emergence": the idea that when certain relations between elements combine to form a whole (or system), the system possesses properties not exhibited by the constituent parts. ${ }^{91}$ For the founder of Gestalt theory, Max Wertheimer (1880-1943), "there are wholes, the behavior of which is not determined by that of their individual elements," termed "holism." ${ }^{92}$ The typical example is that when each individual frame of a movie is flashed up, the frames become something more than the sum of their parts-a moving whole. For Wertheimer and Hayek, this meant conscious phenomena are "isomorphous" with the brain's physical matter-they possess

\footnotetext{
${ }^{87}$ Hayek to Otto Neurath, 21 July 1945, Box 40, Folder 7, Hayek Papers. Friedrich Hayek, "Scientism and the Study of Society," Economica 9/35 (1942), 267-91, at 274.

${ }^{88}$ Friedrich Hayek, "Scientism and the Study of Society. Part III," Economica 11/41 (1944), 27-39, at 32.

${ }^{89}$ Ibid.

${ }^{90}$ Ibid.

${ }^{91}$ Paul Lewis, "Notions of Order and Process in Hayek: The Significance of Emergence," Cambridge Journal of Economics 39/4 (2015), 1167-90, and Lewis, "The Emergence of 'Emergence' in the Work of F. A. Hayek," History of Political Economy 48/1 (2016), 115-50.

${ }^{92}$ Max Wertheimer, "Gestalt theory (Über Gestalttheorie)" (1925), in W. D. Ellis, trans. and ed., A Source Book of Gestalt Psychology (London, 1938), 1-11, 2.
} 
the same basic form, and thus motion, for instance, has an ontological status, actually existing in both the physical world and the mind..$^{93}$

What attracted Hayek to Gestalt theory was not merely its holism, but its claim that mental (consciousness) and neural phenomena could have the same form, while being completely distinct and of different complexities. Paul Lewis argues that Hayek's Gestalt-inspired use of "emergence" is always only a "'practical' form of methodological dualism," a result of Hayek "seeking a more thoroughgoing

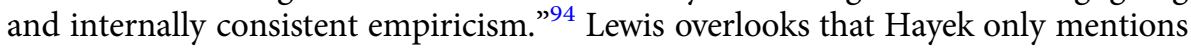
or cites the Berlin school of Gestalt psychology, and never, to my knowledge, any member of the Austrian Graz Gestalt school. It was the latter school that held something closer to the view that Lewis attributes to Hayek: there are wholes in perception and sensation, but the properties of the former are founded upon (Grundlage) its constituent sensations. ${ }^{95}$ In the view of a major multi-author study of the Gestalt tradition, the Berlin school was distinguished in holding that a gestalt was "a whole in itself, not founded on any more elementary objects." 96 The gestalt, for those Hayek cites, is autonomous and not supervenient on its elements. It makes far more sense for this to have been Hayek's view considering the conclusion of TSO: "to us mind must remain forever a realm of its own which we can know only through directly experiencing it, but which we shall never be able fully to explain or to 'reduce' to something else." 97 We might add that, in "Primacy of the Abstract," Hayek said that Helmholtz's ideas, "culminating in the Gestalt school," stressed "that our perception of the external world is made possible by the mind possessing an organizing capacity; and that what used to be called elementary qualities are its product rather than its material." ${ }^{98}$ In other words, the whole makes the parts. This may seem to be at odds with the methodological individualism that Hayek was defending, but his point was that, while the social has properties that are entirely independent of its constituent individuals, those properties are inaccessible, and thus we must limit ourselves to extrapolating speculatively from methodological individualism (the compositive method) when theorizing the social.

Considering the above, we have less trouble reconciling Hayek's statement that there is a "permanent cleavage between our knowledge of the physical world and our knowledge of mental events" with the statement that "ultimately we shall recognize the mental order as part of the physical order." 99 While there are rules common to both orders, and "even though we may know that mental events of the kind which we experience can be produced by the same forces which operate in the rest of nature," the crucial point Hayek was making is that the human brain can never

\footnotetext{
${ }^{93}$ Hayek, TSO, 171.

${ }^{94}$ Lewis, "Emergence of 'Emergence,", 119, 122.

${ }^{95}$ Christian von Ehrenfels, "Über Gestaltqualitäten," Vierteljahrsschrift für wissenschaftliche Philosophie 13 (1890), 249-92.

${ }^{96}$ Johan Wagemans, James Elder, Michael Kubovy, Stephen Palmer, Mary Peterson, Manish Singh, and Rüdiger von der Heydt, "A Century of Gestalt Psychology in Visual Perception," Psychological Bulletin 138/ 6 (2012), 1172-1217, at 1175.

${ }^{97}$ Hayek, TSO, 304, original emphasis.

${ }^{98}$ Hayek, "The Primacy of the Abstract," 317.

${ }^{99}$ Hayek, TSO, 301, 138.
} 
explain its own operation, nor the operation of systems more complex than itself. ${ }^{100}$ This was because "any apparatus of classification must possess a structure of a higher degree of complexity than is possessed by the objects which it classifies."

It has been noted that Hayek's theory of complex systems was influenced by Ludwig von Bertalanffy's general systems theory, but not that Hayek's theory was too metaphysical for the latter. Hayek had approached Bertalanffy (1901-72) in 1947 with "kind words" about his Systemlehre and a ten-year correspondence ensued. ${ }^{102}$ In 1947, Bertalanffy thanked Hayek for his "observation that the mystical 'holism concept' [der mystische "Ganzheitsbegriff"]" in sociology "logically corresponds to a 'vitalism' [Vitalismus]." 103 The preceding letter is not in the archives, so we cannot know whether Hayek was criticizing holism and vitalism, or extolling their virtues for systems theory. Either way, Hayek was clearly too vitalist and holist for Bertalanffy, who told Hayek, "the essence of your system is a holistic [ganzheitliche] view of a far more radical nature than in Gestalt theory, in that it does not only refer to linking elementary conditions or sensations, but the latter are deleted entirely." 104

Hayek's view would get more metaphysical still after his friend Popper prompted him to account for the ground upon which minds communicate with each other. Hayek had sent a draft of TSO to Popper, who drastically misunderstood it. Popper wrote to Hayek saying that he thought Hayek had produced a "causal theory of the mind," and that he would likely see that such a theory was impossible if he read his "paper on the impossibility of a causal theory of the human language." 105 Popper's paper explored "functions" of language in an attempt to reveal a shared understanding that intentionality underlies communication. ${ }^{106}$ His "machine argument" used various examples to show that machines are able to express, signal, and describe things. A "wall thermometer" expresses its internal state, signals the temperature, and describes something about the world. ${ }^{107}$ However, for Popper, "we do not attribute the responsibility for the description to it; we attribute it to its maker." The ability to argue is a crucial function of language, because in arguing with another human, we "attribute to them intentions." 108 "We do not argue with a thermometer" even if it is telling us the incorrect temperature. ${ }^{109}$ It cannot be lying, but merely inaccurate. For Popper, humans attribute intentions to other humans and "we are then 'first movers,' or creators of a physical 'causal chain."'110

\footnotetext{
${ }^{100}$ Ibid., 302. Also see Hayek, "What Is Mind?" 359.

${ }^{101}$ Hayek, TSO, 388.

${ }^{102}$ Hayek to Bertalanffy, 28 Oct. 1947, Box 12, Folder 4, Hayek Papers.

${ }^{103}$ Bertalanffy to Hayek, 10 Nov. 1947, Box 12 Folder 4, my translation.

${ }^{104}$ Bertalanffy to Hayek, 22 June 1950, Box 12 Folder 4, my translation.

${ }^{105}$ Popper to Hayek, 2 Dec. 1952, Box 44, Folder 1, Hayek Papers.

${ }^{106}$ Karl Popper, "Language and the Body-Mind Problem" (1953), in Popper, Conjecture and Refutations (London, 1962), 293-8.

${ }^{107}$ Ibid., 296.

${ }^{108}$ Ibid., 297.

${ }^{109}$ Ibid.

${ }^{110}$ Ibid., 298.
} 
In his response to Popper's letter, Hayek stated he had been "for months puzzling about what just now seems to me the most general problem of all ... what we can say 'within a system' and what we can say 'about a system'."111 Prompted by Popper, he formulated this problem in a new way: if we cannot explain our minds, or systems more complex than them, such as abstract ideas, how is it possible that we can communicate them and even argue over them? ${ }^{112}$ Popper's answer was that we create the shared structures that permit communication. ${ }^{113}$ Hayek's was that the regularities upon which the intentionality behind communication are perceived are inherent in a mind, but those regularities are also shared by other minds, present in the physical world, and determined by a system more complex than all of the above.

Popper's solution to the "communication problem" is found in his "threeworlds" argument. The core tenet was that world three (products of the human mind) provides the basis upon which humans-whose consciousness constitutes world two (mental phenomena, such as thoughts and decisions)-can communicate with each other and explain world one (physical things). ${ }^{114}$ Since at least 1935 (if not in Beiträge), Hayek had also posited an entity "above" the human, and a physical world below the human. In 1935, he stated that the "position of man" was "midway between natural and social phenomena," and in 1952 he spoke of humans existing in the middle of "the order of things." 115 Then, Hayek's view was similar to Popper's because humans were "a cause" of the "complex phenomena" of the social. ${ }^{116}$ By the early 1960s, however, Hayek had diverged from Popper on that point.

For Popper, the more complex system (world three) can only have an effect on the material world when constituent individual minds intervene to make that possible. ${ }^{117}$ But for Hayek, the supersystem can have a causal influence on the physical world independent of our minds, and, most importantly, it provides the basic rules by which our minds, other minds and the physical world operate, including the rule that humans are purposive creatures. Hayek supported Popper's theory that our limited ability to observe phenomena was less important than the conceptual framework with which we observe them, but he went further to say that this conceptual framework was also out of our control, determined instead by higher powers. When Popper concluded his "Language" paper, he said that "the fear of obscurantism (or of being judged an obscurantist) has prevented most antiobscurantists from saying such things as these." ${ }^{118}$ Hayek's views were considerably

\footnotetext{
${ }^{111}$ Hayek to Popper, in Kresge and Wenar, Hayek on Hayek, 24-5.

${ }^{112}$ For the unfinished manuscript, "Within Systems and about Systems: A Statement of Some Problems of a Theory of Communication," see Hayek Papers, Box 104, Folder 22.

${ }^{113}$ Also see Karl Popper "The Worlds 1, 2 and 3," in Karl Popper and John Eccles, The Self and Its Brain (Abingdon, 1983), 36-50.

${ }^{114}$ Ibid.

${ }^{115}$ Friedrich Hayek, Collectivist Economic Planning (London, 1963; first published 1935), 11. Hayek, The Counter-revolution of Science, 38-9.

${ }^{116}$ Hayek, The Counter-revolution of Science, 38-9.

${ }^{117}$ Karl Popper, "Three Worlds," in S. McMurrin, ed., Tanner Lectures on Human Values (Cambridge, 1980), 141-68, at 164.

${ }^{118}$ Popper, "Language and the Body-Mind Problem," 298.
} 
more obscurantist and metaphysical than Popper's, but in the period from World War II until "Rules, Perception and Intelligibility" in 1962, he used a "scientific" language due partly to his fear of being judged an obscurantist and partly to his desire to be understood by those he sought to convince, namely those under the sway of scientism.

Hayek's most Popperian work to my mind is "Degrees of Explanation" (1955), likely a reference to Popper's chapter "Degrees of Testability" in Logic of Scientific Discovery. ${ }^{119}$ Primarily employing a mathematical approach, "Degrees of Explanation" argued that the scientist must be metaphysical about complex phenomena considering "the existing state of observational technique." ${ }^{20}$ From this, one sees why this paper has contributed to the inaccurate view that Hayek thought the three realms he was describing (less complex, mind, and more complex) were merely distinguished by degree of complexity, rather than by qualitative or ontological differences. However, even in "Degrees of Explanation" Hayek made clear that there was a qualitative divide resulting from our position in the middle of a universe of complex systems. Drawing on Popper's hypothetico-deductive philosophy of science, Hayek claimed that we inevitably reach a point where our "imagination" can tread no further, and that then "no systematic testing will help us."121 There will always be a "cleavage" between the explicable and the necessarily inexplicable because of our inability to think about complex phenomena other than simply conceiving of their existence. Hayek might have stopped there and employed an Anselm-Descartes ontological argument for the existence of a supersystem. But his purpose was to defend his metaphysical science, not to be a sort of undercover theologian. He found the defense he needed in set theory.

In "Rules, Perception and Intelligibility," Hayek referred the reader to Georg Cantor (1845-1918) for the "proof" that he did "not feel competent to attempt."122 Cantor's proof that Hayek refers to is that of the "actual infinite" (Aktual-Unendliche) or the "absolute," which Cantor described as "the completely independent, extraworldly [außerweltlichen] existence, in Deo."123 The proof was immensely controversial because he not only believed that it proved the existence of a Christian God (not a "materialist, positivist, or pantheist" one), but that God him-/herself had communicated the theory to him. ${ }^{124}$ Hayek went on to cite the Ernest Nagel and James Newman book on the Cantor-influenced incompleteness theorem of Kurt Gödel, which described how the latter theorem proved that no system can prove its own consistency and any explanation of itself will always remain incomplete. ${ }^{125}$ The upshot was that we can never "yield formally all arithmetical truths" and, therefore, there will always be true facts about numbers

\footnotetext{
${ }^{119}$ Friedrich Hayek, "Degrees of Explanation" (1955), in Hayek, Collected Works, 15: 195-212.

${ }^{120}$ Ibid., 200.

${ }^{121}$ Ibid.

${ }^{122}$ Hayek, "Rules, Perception and Intelligibility," 61 n. 49.

${ }^{123}$ Georg Cantor, "Mitteilungen zur Lehre vom Transfiniten," in Cantor, Gesammelte Abhandlungen, ed. E. Zermelo (Hildesheim, 1962), 378-439, at 378, my translation.

${ }^{124}$ Expressed by Cantor in a letter to Gösta Mittag-Leffler in 1884, cited in Joseph Dauben, Georg Cantor (Princeton, 1990), 146.

${ }^{125}$ Hayek, "Rules, Perception and Intelligibility," 62. Ernest Nagel and James Newman, Gödel's Proof (New York, 2001), 5, 94.
} 
that any one set of mathematical axioms cannot encompass. ${ }^{126}$ There will always be a further, hidden "reality" beyond our best (formal) attempts to understand it. Both Cantor and Gödel were invoked by Hayek in order to show that the rules upon which communication, the mind, and the universe operate cannot be grasped by any single system, let alone our minds.

Hayek could feasibly have held that systems increase in complexity ad infinitum. But if we are nested within an infinite number of systems that increase in complexity forever, then we have no reason to believe that the rules common to our system might not be altered drastically by any number of potential changes occurring in higher systems. The argument may have "worked," but it left humanity in chaos, which certainly did not fit with Hayek's view that our institutions and religions have "learnt" the consistent general rules that are incomprehensible to individuals. Hayek needed to affirm the existence of a supra-conscious and all-encompassing system, a rule giver that gave humans a "position," "place," and "meaning" in the world. We know that Hayek was concerned about these issues because in "Rules, Perception and Intelligibility" he stated that for twenty years he had been thinking about the problem of how "we are not to be led into an infinite regress" by the implications of his idea of ever-higher systems determining the rules upon which events occur within them. ${ }^{127}$ Hayek's solution was that there must be "a supraconscious order which cannot be the object of its own representations." ${ }^{28}$ By this, he meant that there must be a system that does not think about itself-not the physical or natural world but something separate that bestows us with a "distinct place" in the "order of things," and thereby with a "meaning."

\section{IV}

This article has already shown the way in which purposiveness was a persistent feature of Hayek's work since 1920. This section explains why this was so, offering two primary and related reasons: (1) Hayek was always enthralled by and in agreement with vitalism, phenomenology, and praxeology on the a priori existence of a vital force, and (2) Hayek wanted to improve on Mises's argument for praxeology's core belief in innate human purposiveness.

The interested reader can explore the cavernous debates concerning whether Hayek did or did not accept Mises's axiom of action, but here it is only necessary to briefly state my view that he accepted its core premises, but thought they needed stronger justifications. In 1978, Hayek stated, "I was always influenced by Mises's answers, but not fully satisfied by his arguments-it became very largely a thing to improve the argument which I realised led to correct conclusions ... so I became anxious to put it in a more effective form." 22 What appears to many as a volte-face in Hayek's thought in 1936 can just as well be seen as him applying early psychological ideas expressed in Beiträge, and phenomenological ideas from Freiburg, to economic analysis. It was then clear to Hayek that Mises's apriorism about

\footnotetext{
${ }^{126}$ Nagel and Newman, Gödel's Proof, 103, original emphasis.

${ }^{127}$ Hayek, "Rules, Perception and Intelligibility," 61.

${ }^{128}$ Ibid.

129"Hayek Interviewed by Craver," 13.
} 
action-that man's constant interaction with the world is inescapable and imperative-must be a "first step" in social science. In TSO, Hayek wrote that "in the study of human action our starting point will always have to be the ... direct ("introspective') knowledge of mental events." ${ }^{\prime 30}$ Regarding "the science of 'praxeology," Hayek thought that "on the main point Professor Mises's lone voice seems to [him] considerably nearer the truth than the commonly accepted views." 131 Hayek accepted the core tenet of praxeology-that choice of action must be considered an a priori truth-but insisted that it occurred within rules set by the supersystem. He did so in consistent opposition to the empiricism of prevailing sciences, both natural and social.

Sometimes, it seemed as if Hayek avoided the problem of accounting for intentionality by explaining it as something that we project onto the world. We have seen that Hayek thought that maintaining the existence (for all we can possibly know) of free will is unavoidable because we cannot ever interpret another human's decisions or utterances without projecting our innate purposiveness onto them. But Hayek also held that we project purposiveness onto nature. In later life, he recalled rushing home after attending one of his first lectures at Vienna, on Aristotle, to tell his father that he wanted to study ethics. ${ }^{132}$ His father dutifully purchased him three volumes of Feuerbach, whose work is largely dominated by the notion of "anthropotheism"- that God is a projection of characteristics or features within humans themselves. In Hayek's final work, The Fatal Conceit, he criticized humanity's tendency to envisage a "human-like divinity," or an "omniscient God," rather than a more accurate interpretation of the supersystem, which is "far too complex for any of its parts to form an 'image' or 'picture' of it." 133 Like his friend and Chicago schooler Frank Knight, Hayek was interested in the positions of Buddhism and Shintoism, approving of their "profound respect for the existence of other orderly structures in the world, which they admit they cannot fully understand and interpret." ${ }^{\prime 34}$ Indeed, in Fatal Conceit, Hayek drew a line back to his earliest work by reaffirming that social science should not be based on the "rationalist requirements" of "what Ernst Mach called the 'observable and tangible."'135

Projection of our inner states onto nature was considered a crucial proxy through which we can glimpse aspects of what occurs inside the black box of our minds. For Hayek, "expressions such as that a thundercloud leans threateningly over us" do not help us understand nature per se. ${ }^{136}$ Rather, "that those patterns we read (or project) into nature are all that we know and all that determines our action makes it an essential datum in our efforts to explain the results of human interaction." ${ }^{\prime 37}$ What projections of our inner states do, for Hayek, is help us understand the way in which our mind inherently attributes meaning to all manner of things, crucial to the work of the social scientist, who is likened in this passage to "the poet

\footnotetext{
${ }^{130}$ Hayek, TSO, 191-2.

${ }^{131}$ Hayek, “Review of Mises's Nationalöknomie," 152.

132"Hayek Interviewed by Craver," 21.

${ }^{133}$ Friedrich Hayek, The Fatal Conceit (London, 1992; first published 1988), 140.

134"Hayek Interviewed by Chitester," 489.

${ }^{135}$ Hayek, The Fatal Conceit, 89.

${ }^{136}$ Hayek, "Rules, Perception and Intelligibility," 52.

${ }^{137}$ Ibid., my emphasis.
} 
or painter." 138 This was both Kant's and Mises's view, the former holding that in order to "conduct research" it is "indispensable for us to subject nature to the concept of an intention," and the latter that the study of human action is always a "projection into the external world of becoming and change." ${ }^{139}$ In "Rules, Perception and Intelligibility," Hayek also commended "the vitalists" opposition to "causal explanations of the phenomena of life" because "such explanations do not account for those features by which we intuitively recognize something as living." ${ }^{140}$ But projection of human purposiveness alone, however, was insufficient as a foundation for praxeology.

A significant influence on Hayek's thinking here was Schutz. Along with many phenomenologists, Schutz considered meaning behind actions crucial. Schutz was as close to Mises as he was to Hayek, and, as Thomas Eberle puts it, "Schutz agreed with Mises that a basic social theory should search for aprioris," but he thought a prioris should not be founded on "laws and principles, but are to be found on a much more fundamental level, namely in the constitutive features of the lifeworld." 141 This was the same turn away from Mises that Hayek took, as seen when Hayek presented a draft of his crucial "Economics and Knowledge" paper in Vienna in 1936, with Schutz as the discussant. ${ }^{142}$ Schutz's response bears marked resemblance to Hayek's paper published later that year. ${ }^{143}$ Likely responding to a question asked in Hayek's draft, Schutz stated, "To whom are such data given? To me, living in my everyday life, the whole environment, as it were." ${ }^{144}$ In Hayek's published paper, "Datum means, of course, something given, but the question which is left open ... is to whom the facts are supposed to be given." 145 For Hayek, Schutz's ideas accounted for what was unique about humans and their "free" choices-it was not their purposive action alone, but the meaning and significance behind them.

Hayek explored transcendental phenomenology, and then philosophical anthropology, throughout his life. ${ }^{146}$ Hayek quoted Ernst Cassirer's Mythical Thought (Das mythische Denken) in expressing what he considered the "truth" that "action forms the centre from which man undertakes the spiritual organisation [die geistige Organisation] of reality." ${ }^{147}$ In "Rules, Perception and Intelligibility," Hayek also

\footnotetext{
${ }^{138}$ Ibid.

${ }^{139}$ Immanuel Kant, Critique of the Power of Judgment, trans. E. Matthews (Cambridge, 2000), 269. Mises, Human Action, 36.

${ }^{140}$ Hayek, "Rules, Perception and Intelligibility," 55.

${ }^{141}$ Thomas Eberle, "In Search for Aprioris: Schutz's Life-World," in H. Nasu, L. Embree, G. Psathas, and I. Srubar, eds., Alfred Schutz and His Intellectual Partners (Konstanz, 2009), 493-18, at 501.

${ }^{142}$ Christian Knudsen, "Alfred Schutz, Austrian Economists and the Knowledge Problem," Rationality and Society 16/1 (2004), 45-89, 61.

${ }^{143}$ Alfred Schutz, "Political Economy: Human Conduct in Social Life" (1936), in Schutz, Collected Papers, vol. 4 (Dordrecht, 1996), 93-105.

${ }^{144}$ Ibid., 96.

${ }^{145}$ Hayek, "Economics and Knowledge," Economica 4/13 (1937), 33-54, at 38-9.

${ }^{146}$ See Mark J. Smith, Situating Hayek: Phenomenology and the Neo-liberal Project (London, 1999). Mark Peacock, "Hayek, Realism and Spontaneous Order," Journal for the Theory of Social Behavior 23/3 (1993), 249-64, at 263, notes Hayek and Schutz's friendship and methodological similarities.

${ }^{147}$ Hayek, "The Primacy of the Abstract," 320. In the same work, Hayek likened his "Primacy of the Abstract" to Maurice Merleau-Ponty's "primacy of perception." Ibid., 317.
} 
praised the Catholic-influenced strand of Lebensphilosophie for their work on "action patterns." For instance, he read and cited F. J. J. Buytendijk-the phenomenological psychologist and philosophical anthropologist who converted to Catholicism through Max Scheler, himself a convert-especially endorsing his "The First Smile of the Child" ("Die Erste Lächeln des Kindes," 1947), which explored the "secret alliance between animated corporeality and spiritual existence" in order to reveal how spiritual matters such as "significance and meaning" are just as important for understanding human phenomena as psychology or physiology. ${ }^{148}$ Hayek also cited Helmuth Plessner, who extended Scheler's philosophical anthropological project to seek humanity's "metaphysical position or location within the whole of being, the world and God" (albeit without Scheler's explicit Catholicism). ${ }^{149}$ These Catholic-influenced Lebensphilosophen accounted for the origin of purposiveness and therefore of understanding as an act of "God," and Hayek, I propose, assigned the same acts to his supersystem.

In contrast, Francesco Di Iorio claims that Hayek considered the supersystem to be the "cause of itself." 150 Though Hayek did occasionally refer to the supersystem as "self-organizing," and even once as "self-generating," he usually put those terms in scare quotes. ${ }^{151}$ Contra Di Iorio, what strikes the reader is that Hayek never seemed to describe the system as being causa sui, but most of the time referred to the supersystem and order as having a vital force that is forever mysterious. Indeed, for all his habitual expressions of scorn for Descartes's rationalism, Hayek admitted that his resolution to represent "the unfathomable will of God as the creator of all purposive phenomena" was to be preferred to the beliefs of "his successors," for whom "it certainly became a human will."152 It was not simply that believing in God was the lesser philosophical evil, but that the idea of a finite system providing humanity with a unique meaning and a fixed position in the order of things was important in explaining why we should believe in free will but also in preordained restrictions on our behavior.

For Hayek, while there are "general principles" that may mean that human actions are "causally determined," we nonetheless have purposiveness within those bounds. ${ }^{153}$ Explicitly aligning his view with Bergson-whose Time and Free Will had caused a stir in the germanophone world after translation in 1911Hayek concluded all three of his major psychological works by stating that his findings supported the fact that free will must necessarily be considered an a priori truth. The concluding chapter of TSO concerned the "age-old controversy about the 'freedom of the will." Hayek's position was that "even though we may know the general principle by which all human action is causally determined by physical

\footnotetext{
${ }^{148}$ Hayek, "Rules, Perception and Intelligibility," 57, citing F. J. J. Buytendijk, "The First Smile of the Child," Phenomenology + Pedagogy 6/1 (1988), 15-24.

${ }^{149}$ Max Scheler, Vom Ursturz der Werte (Bern, 1955), 173.

${ }^{150}$ Francesco Di Iorio, "The Sensory Order and the Neurophysiological Basics of Methodological Individualism," in Butos, The Social Science of Hayek's "The Sensory Order", 187-9.

${ }^{151}$ Hayek, "Evolution of Systems," 74. For scare quotes see Friedrich Hayek, "Competition as a Discovery Procedure" (1968), in Hayek, Collected Works, 15: 309. For self-generating, see Hayek, Law, Legislation and Liberty, 37.

${ }^{152}$ Friedrich Hayek, "Errors of Constructivism" (1970), in Hayek, Collected Works, 15: 338-9.

${ }^{153}$ Hayek, "The Primacy of the Abstract," 327.
} 
processes ... To us human decisions must always appear as the result of the whole of a human personality." 154 It was in this way that Bergson helped Hayek formulate arguments to defend the axiom of action as a fundamental epistemological truth.

Hayek's view bore resemblance to Augustine's compatibilism, according to which "wills are themselves included in the order of causes which is certain to God." ${ }^{155}$ Indeed, Hayek looked to Augustine when explaining the history of the concept of "spontaneous order," citing both an English and a German edition of his dialogue "Ordo." ${ }^{156}$ Moreover, in his biography of his distant cousin, Ludwig Wittgenstein, Hayek emphasized that Confessions was Wittgenstein's favorite book, with Tolstoy's Gospels in Brief a close second. ${ }^{157}$ The biography is a fascinating insight into Hayek's own thought, as he tried to claim probably the most famous philosopher in the Western world as a proponent of a more spiritualistic form of science. ${ }^{158}$ After drawing a parallel between himself and Wittgenstein's "experimental work in the Psychological Laboratory," as well as describing what a mesmerizing man he was for the logical empiricists and men of science-describing, for instance, Schlick's "pilgrimage" to see Wittgenstein-Hayek offered abundant evidence of Wittgenstein's spirituality. ${ }^{159}$ Overcoming his "spiritual loneliness" once in Cambridge, Wittgenstein was, for Hayek, "not a dogmatic believer, yet, in a sense a prof/o/undly [sic] religious man." 160

V

This section briefly outlines why Hayek's belief in his spiritualistic science is an important discovery for scholars of neoliberalism and contemporary Western politics more widely. Despite repudiating characterizations of himself as a proponent of "neoliberalism" or even "capitalism," Hayek remains perhaps the most influential "neoliberal" thinker. ${ }^{161}$ It is therefore significant that his project was not about removing sovereignty from God, the Church, or the state, as Brown holds, but about reinstating those institutions as the guardian of tradition in the face of any group who claims to offer a vision of a new society. ${ }^{162}$ Yet the aporia one is led into is that Hayek's Mont Pèlerin Society was an insurgency group whose purpose was to counter the considerably more popular and arguably more "evolutionary" socialist or state socialist traditions.

\footnotetext{
${ }^{154}$ Hayek, TSO, 302-3.

${ }^{155}$ Augustine, De Civitate Dei, V, 9.

${ }^{156}$ LLL 1, 155.

${ }^{157}$ Friedrich Hayek, Draft Biography of Ludwig Wittgenstein, ed. C. Erbacher (Leiden, 2019), 57.

${ }^{158}$ In Hayek, "Rules, Perception and Intelligibility," 45, Hayek quoted Wittgenstein-“'Knowing it' only means: being able to describe it"-to support his point that the Sprachgefühl (an intuitive ability to use language) "consists in our capacity to follow yet unformulated rules." On the next page, Hayek affirmed Wittgenstein's "ostensive" teaching-communication theory. Cf. Ludwig Wittgenstein, Philosophical Investigations (Oxford, 1986), 228.

${ }^{159}$ Hayek, Draft Biography of Ludwig Wittgenstein, 36, 67.

${ }^{160}$ Ibid., 61.

${ }^{161}$ Friedrich Hayek, "From Servitude to Liberty," interview with Lucia Santa Cruz, El Mercurio, 19 April 1981, D1-D2.

${ }^{162}$ Hayek, The Fatal Conceit, 135.
} 
The way out of this aporia, I propose, is found in the fact that Hayek realized, in the 1940s, that science was ideological in that it was a result of faith in a liberal creed. In The Road to Serfdom, Hayek wrote that in a socialist or fascist country there must be "a generally accepted creed which makes the individuals as far as possible act spontaneously in the way the planner wants," but, crucially, the planner must make "everybody believe in those ends." ${ }^{163}$ Hayek soon realized that liberalism could also be criticized because it was a creed, and, worse, it was a creed that people often did not even have to be persuaded to follow, but did so "merely out of tradition." ${ }^{164}$ He knew he would have to show that liberalism, though an ideology, was nonetheless a prerequisite for more accurate scientific work, that would also serve desirable ends.

This article helps us understand why Hayek saw "a close connection between the ideals of science and the ideals of personal liberty," and why he established a close friendship with Michael Polanyi (1891-1976), an early Mont Pèlerin member, Catholic convert, and founder of the Society for Freedom in Science. ${ }^{165}$ For Polanyi, the "problem" of man needing a purpose in science "cannot be attained on secular grounds alone." ${ }^{166}$ Hayek and Polanyi were in frequent correspondence about their projects to reunite science with spiritual concepts of reality and meaning. ${ }^{167}$ Polanyi thought "Christian worship" most profitable for the scientist because of its "assumption that the world has some meaning," and its "obsession with a problem known to be insolvable, which yet follows, against reason, unswervingly, the heuristic command: 'Look at the unknown!"”168 This corresponds closely to Hayek's science extrapolated above, which stresses that the supersystem provides purposiveness and meaning, as well as an actually existing reality to investigate. To theorize the "supernatural aspect of experience which Christian interpretations of the universe explore," for Hayek and Polanyi alike, was "our calling." 169

Hayek returned to his earlier work in psychology and explored "natural"-scientific disciplines after the war not to disguise ideology as science, but to show that science was ideological. One despairs upon reading Hayek's defenders claiming that he thought "positive claims must be kept separate from normative ones." ${ }^{" 170}$ In fact, in his inaugural lecture for the chair in political economy at Freiburg, Hayek said that Weber went "too far" with the fact/value distinction, which "unfortunately has often produced a fear of expressing any value

\footnotetext{
${ }^{163}$ Friedrich Hayek, The Road to Serfdom (Chicago, 2007), 171

${ }^{164}$ Hayek, The Constitution of Liberty, 62-3, original emphasis. For "merely out of tradition" see Friedrich Hayek, "Opening Address to a Conference at Mont Pèlerin" (1947), in Hayek, Studies in Philosophy, Politics and Economics, 148-59, at 151. Hayek had perhaps already realized that liberalism was a creed while reading Walter Lippmann's The Good Society. See Burgin, Great Persuasion, 55-85; and Ben Jackson, "Freedom, the Common Good, and the Rule of Law: Lippmann and Hayek on Economics," Journal of the History of Ideas 73/1 (2012), 47-68.

${ }^{165}$ William McGucken, "On Freedom and Planning in Science: The Society for Freedom in Science," Minerva 16/1 (1978), 42-72, at 45. Tomas Torrance, "Michael Polanyi and the Christian Faith: A Personal Report," Tradition and Discovery 27/2 (2000), 26-33.

${ }^{166}$ Michael Polanyi, The Tacit Dimension (London, 1966), esp. 92.

${ }^{167}$ See Hayek Papers, Box 78, Folder 35, and Box 43 Folder 35.

${ }^{168}$ Michael Polanyi, Personal Knowledge (London, 1962), 199.

${ }^{169}$ Ibid., 284-5.

${ }^{170}$ Bruce Caldwell, "Introduction," in Hayek, Collected Works, 15: 1-38, at 20.
} 
judgments." ${ }^{171}$ In truth, "the very selection of our problems for scientific examination implies valuations." We can now make sense of why Hayek praised Marx and Pigou for their philosophical and theological work. ${ }^{172}$ Hayek had respect for "socialists" who recognized that ideology was inherent in science, seeing considerably more danger in "disillusioned socialists" who had "been forced by the inherent contradictions of their own ideology to discard it." 173 These socialists "concluded that all ideologies must be erroneous and that in order to be rational one must do without one." Ideology, for Hayek, was often more rational and scientific than the prevailing positivist science. There is thus an irony when his defenders claim to take a neutral, "scientific" approach in their economics, when, to Hayek's own mind, such an approach would be potentially more damaging for society than the work of his socialist critics.

Indeed, in his "Opening Address" to the Mont Pèlerin Society's founding conference, with Polanyi in attendance, Hayek announced that the core topics of discussion would be the design of the "complete programme of a liberal economic policy," the "interpretation" of history, and what he thought was an equally important project: healing the "breach between true liberal and religious convictions." 174 Hayek lamented that the "fierce rationalism" of prevailing science had "driven religious people from the liberal movement," and he was "specially anxious that the subject of the relation between liberalism and Christianity" be discussed. ${ }^{175} \mathrm{He}$ thought that showing liberalism, religion, and tradition were "scientific" would be the greatest contribution he could make to both science and liberalism.

This was not merely rhetoric. In an interview in the Chilean paper El Mercurio, Hayek recounted meeting Pope John Paul II with eleven other Catholic Nobel laureates to discuss "the reconciliation of science and the Church." ${ }^{176}$ Hayek thought that "there was a lot of hope." While he was a "globalist," he also believed in the need for robust moral authority and a firm rule of law, so it is not surprising that he saw virtue in the transnational spiritual authority of Pope and Church. Section I showed that explaining how such religious sympathies fitted with his science and economics has posed difficulties for scholars. The answer I have provided is that Hayek did not think science was separate from metaphysical or spiritual concerns.

\section{CONCLUSION}

This article has shown that Hayek thought science necessarily posited the existence of a supernatural entity that lays down the general rules by which the universe operates and provides humans with a unique position in the universe from which they can explain the world and-to a limited extent-each other. It has explained that the core premise of Hayek's science and epistemology was developed during his

\footnotetext{
${ }^{171}$ Friedrich Hayek, "The Economy, Science and Politics" (1962), in Hayek, Studies in Philosophy, Politics and Economics, 251-69, at 253.

${ }^{172}$ Ibid., 264.

${ }^{173} L L L 1,58$.

${ }^{174}$ Hayek, "Opening Address," 154-5.

${ }^{175}$ Ibid.

176“Servitude to Liberty," D2.
} 
student days in Vienna, though mostly through non-positivist German influences. In doing so, a larger point has been made-Hayek genuinely believed in the truth of his "science" and the epistemological arguments he proposed in support of his political project. A more accurate science, for Hayek, was one that did not ignore that which is beyond the physical, but rather tried to prove its existence and its influence on all aspects of our thought and behavior while simultaneously emphasizing that we can know very little about it.

Forthrightly religious "neoliberals" like Wilhelm Röpke were not anomalous. ${ }^{177}$ "Neoliberal" thought took itself to be answering a far broader set of concerns than the economic, political, scientific, or even moral. The stakes of the "neoliberal" project, for Hayek, were on a metaphysical level, encompassing questions such as how we understand humans, their actions, and their ideas. The battle to save civilization required justifying previously held beliefs about humanity's definite place in the order of things, as well as affirming the meaning and significance of human action and endeavors.

In terms of the appeal of these ideas more widely, Hayek offered a view of the world that would prove attractive not merely to those of the same philosophical and political persuasion, but to those "who have faced the arguments from the other side." ${ }^{178}$ His account of the world granted free will and reason to humans, but within the bounds of an overseer. If collective human will could be kept within supra-consciously determined bounds, Hayek promised an ever-richer society that was not materialistic but in accordance with the history and purpose of humanity. His concept of the "spontaneous order," which occurred at levels higher than the market, had defined a place for humanity as a whole but also for each individual within that whole. Perhaps Hayek's offer is similar to that of religious conservatism in that they both make claims to marry order, freedom, and purpose.

Acknowledgments. I am extremely grateful to Sarah Patton and Diana Sykes at the Hoover Institution for their help; to the three Modern Intellectual History reviewers and editors for their invaluable comments; and to Duncan Bell, Duncan Kelly, Lucie Davidson, Molleigh Maree, Luke Illot, and Efthimios Karayiannides for advice and insightful comments on former attempts of this article.

\footnotetext{
${ }^{177}$ For Röpke see Slobodian, Globalists, 22, 156-7; and Whyte, The Morals of the Market, 186.

${ }^{178}$ Hayek, “Opening Address," 151.
}

Cite this article: O'Shea J (2022). Hayek's Spiritual Science. Modern Intellectual History 19, 473-498. https://doi.org/10.1017/S1479244320000517 